\title{
Perception of Employees towards Recruitment Process Adopted by KGISL, Coimbatore
}

\author{
Nandha Kumar, S Praveen Kumar
}

\begin{abstract}
Enrollment insinuates the path toward attracting, screening, and picking qualified people for a work at an affiliation or firm. For specific pieces of the selection strategy, mid-and enormous size affiliations as often as possible hold capable choice delegates or re-proper a bit of the technique to enlistment workplaces. The selection business has five crucial sorts of associations: work workplaces, enlistment locales and mission for new work engines, "head trackers" for official and master enlistment, claim to fame workplaces which have pragmatic involvement in a particular zone of staffing and in-house enlistment. The stages in enrollment fuse sourcing candidates by publicizing or various procedures, and screening and picking potential up-and-comers using tests or gatherings. Sensibility for an occupation is generally overviewed via looking for capacities, for instance correspondence, creating, and PC capacities. Capacities may be showed up through resume, demands for work, interviews, informational or master involvement, the revelation of references, or in-house testing, for instance, for programming getting the hang of, creating capacities, numeracy, and capability, through mental tests or business testing. Other resume screening criteria may consolidate length of organization, work titles and timeframe at an employment. In specific countries, organizations are legally directed to give identical open entryway in enrolling. Business the board writing computer programs is used by various enrollment associations to modernize the testing methodology. Various determination delegates and associations are using a competitor following structure to play out a critical number of the filtering tasks, close by programming gadgets for psychometric testing.
\end{abstract}

Keywords: Recruitment, professional experience, psychometric testing

\section{INTRODUCTION}

As numerous abilities and skills join to acknowledge innovation driven business changes, programming advancement keeps on being the biggest programming building action crosswise over ventures. Drivers for custom-fabricated answers for customers depend on inventive utilization of innovation to accomplish upper hand and separation. KGISL's well-sharpened abilities and administration philosophies address explicit needs of big business IT projects, and Internet innovation item advancement[1],[3],[5].

Revised Manuscript Received on July 22, 2019

Nandha Kumar, Department of MBA, Bharath Institute of Higher Education and Research, Chennai, India.

Email: praveenkumar.mba@bharathuniv.ac.in

Dr S Praveen Kumar, Department of MBA, Bharath Institute of Higher Education and Research, Chennai, India.

Email: praveenkumar.mba@bharathuniv.ac.in
KGISL IT administrations supplement to characterize, upgrade and adjust undertaking business technique with innovation activities in a far reaching IT re-appropriating structure that guarantees financially savvy and productive administration of client IT tasks. KGISL gives both start to finish arrangements (investigation to upkeep) and explicit structure/improvement administrations.

KGISL is a pioneer in the field of Business Process Outsourcing administrations to India[2 ],[4],[6] . Situated in India, KGISL has solid infrastructural and scholarly qualities; reasonably used to develop the innovation and procedure that makes KGISL the achievement it is today. KGISL BPO Services division is a main abroad specialist organization made with the goal of giving reasonable quality administrations to different vertical industry portions in the US like Healthcare, Legal, Insurance, Business and Finance.

Pretty much every business can move toward becoming overpowered and accumulated by the gigantic volume of paper that creates huge amounts of information which requires arranging and examination to be handled. Banks, Financial Institutions, Airlines, Healthcare, insurance agencies, government offices, medical clinics, publicizing, and retailers are organizations that normally handle shapes that have been rounded out by people or are machine-produced[7],[9],[11]. Business elements are needy upon speed and exactness as this directly affects their proficiency, assets and benefits.

KGISL offers a wide scope of information catch and record the executives answers for suit support, distributing, logical and building applications, protection and therapeutic structures.

\section{METHODOLOGY}

Research reasoning is a way to deal with methodicallly deal with an investigation issue. The method draws out the investigation plan, nature and methodologies got for social event of data and the quantifiable devices used in examination and explanation, isolating rate and tables[8],[10],[12].

\section{A. Area of study}

This study was under taken at KGISL located in Coimbatore district, Tamil Nadu.

\section{B. Tools For Analysis \\ The accompanying} apparatuses were utilized to break down the gathered 


\section{Perception Of Employees Towards Recruitment Process Adopted By KGISL, Coimbatore}

information and to touch base at the significant outcomes. Straightforward rate and Chi-square examination were utilized. Bar outlines and pie diagrams were utilized to extend the examination of information unmistakably.

\section{Simple Percentage Method}

One of the apparatuses utilized for breaking down the information is rate strategy. Rate alludes to an exceptional sort of apportion, which is utilized to depict relationship rate diminishes everything to a typical base and there by enables important correlation with be made[13], [15],[17].

\section{FORMULA}

$$
\text { No. of respondents }
$$

Percentage $=$ X 100

Total No. of respondents

\section{Chi-Square Method}

Chi-square Test is a significant test among the few trial of centrality. It is a factual measure utilized with regards to testing examination for contrasting a change with a hypothetical fluctuation.

Chi-square test empowers to clarify whether two qualities are related. Chi-square is determined as pursues, FORMULA

$$
\text { - } 2=\cdot(\mathrm{Oij}-\mathrm{Eij}) 2 / \mathrm{Eij}
$$

Oij = observed frequency of the cell in the ith row and jth column.

Eij $=$ expected frequency of the cell in the ith row and jth column.

As a non parametric test it can be used to determine a categorical data. It is used to make a comparison between theoretical population and actual data[14],[16], [18].

Degree of freedom plays an important part in using the chi-square distribution and tests are based on it. The degree of freedom is worked out as follows:

d.f $=(\mathrm{c}-1)(\mathrm{r}-1)$

Where ' $c$ ' means number of columns and ' $r$ ' means number of rows.

\section{DATA ANALYSIS AND INTERPRETATION}

Table - 1 Table showing the age group of the Respondents

\begin{tabular}{|l|l|l|l|}
\hline S. No & Age & $\begin{array}{l}\text { No. } \\
\text { Respondents }\end{array}$ & Of \\
\hline 1 & $21-30$ years & 58 & 59 \\
\hline 2 & $31-40$ years & 22 & 22 \\
\hline 3 & $41-50$ years & 18 & 19 \\
\hline & TOTAL & $\mathbf{9 8}$ & $\mathbf{1 0 0}$ \\
\hline
\end{tabular}



Figure - 1 Table showing the age group of the Respondents

Table -2 Gender of the respondents

\begin{tabular}{|l|l|l|l|}
\hline S. No & Gender & $\begin{array}{l}\text { No. } \\
\text { Respondents }\end{array}$ & Percentage \\
\hline 1 & Male & 46 & 47 \\
\hline 2 & Female & 52 & 53 \\
\hline & TOTAL & $\mathbf{9 8}$ & $\mathbf{1 0 0}$ \\
\hline
\end{tabular}

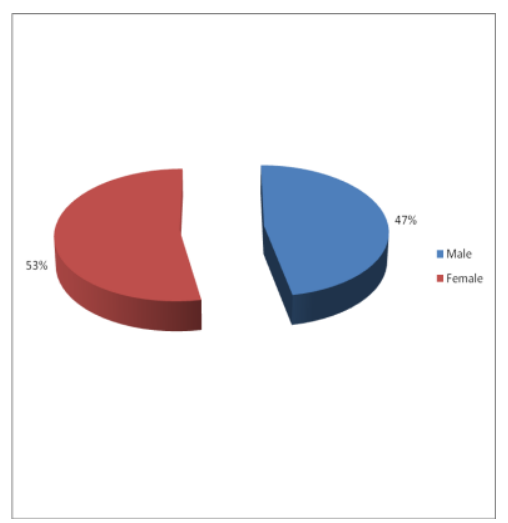

Figure -2 Gender of the respondents

Table - 3 Educational qualification of the respondents

\begin{tabular}{|l|l|l|l|}
\hline S. No & Experience & $\begin{array}{l}\text { No. Of } \\
\text { Respondents }\end{array}$ & Percentage \\
\hline 1 & Academic & 58 & 59 \\
\hline 2 & Technical & 40 & 41 \\
\hline & TOTAL & $\mathbf{9 8}$ & $\mathbf{1 0 0}$ \\
\hline
\end{tabular}




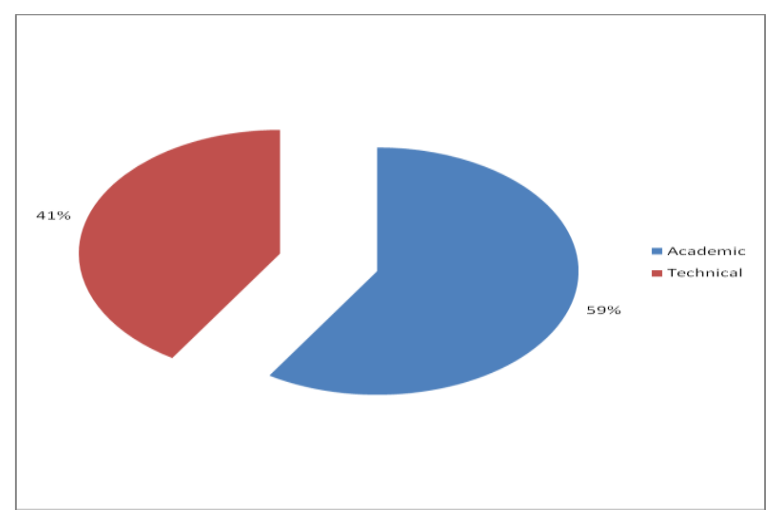

Figure - 3 Educational qualification of the respondents

\section{Chi - Square Test No: 1}

\section{Null Hypothesis H (0):}

There is no significant relationship between experience and job satisfaction among the employees.

\section{Alternative Hypothesis H (1):}

There is a significant relationship between experience and Job satisfaction among the employees.

\begin{tabular}{|l|l|l|l|l|l|l|}
\hline FACTORS & & \multicolumn{5}{|l|}{ TOTAL } \\
\cline { 2 - 7 } & $\begin{array}{l}\text { Highly } \\
\text { Satisfied }\end{array}$ & Satisfied & Neutral & Dissatisfied & $\begin{array}{l}\text { Highly } \\
\text { Dissatisfied }\end{array}$ & Total \\
\hline $21-30$ & 25 & 25 & 8 & 0 & 0 & $\mathbf{5 8}$ \\
\hline $31-40$ & 10 & 8 & 4 & 0 & 0 & $\mathbf{2 2}$ \\
\hline $41-50$ & 10 & 4 & 4 & 0 & 0 & $\mathbf{1 8}$ \\
\hline TOTAL & $\mathbf{4 5}$ & $\mathbf{3 7}$ & $\mathbf{1 6}$ & $\mathbf{0}$ & $\mathbf{0}$ & $\mathbf{9 8}$ \\
\hline
\end{tabular}

\begin{tabular}{|l|l|l|l|l|l|}
\hline CELL & $\mathbf{O}$ & $\mathbf{E}$ & $\mathbf{O}-\mathbf{E}$ & $\mathbf{( O - E}^{\mathbf{2}}$ & $(\mathbf{O}-\mathbf{E})^{\mathbf{2}} \mathbf{E}$ \\
\hline R1C1 & 25 & 26.63 & -1.63 & 2.657 & 0.099 \\
\hline R1C2 & 25 & 21.89 & 3.11 & 9.672 & 0.442 \\
\hline R1C3 & 8 & 9.46 & -1.46 & 2.136 & 0.226 \\
\hline R1C4 & 0 & 0 & 0 & 0 & 0 \\
\hline R2C1 & 0 & 0 & 0 & 0 & 0 \\
\hline R2C2 & 10 & 10.10 & -.10 & 0.01 & 0.001 \\
\hline R2C3 & 8 & 8.30 & -.30 & 0.09 & 0.010 \\
\hline R2C4 & 4 & 3.59 & .41 & 0.168 & 0.046 \\
\hline R3C1 & 0 & 0 & 0 & 0 & 0 \\
\hline R3C2 & 0 & 0 & 0 & 0 & 0 \\
\hline R3C3 & 10 & 8.26 & 1.74 & 3.027 & 0.367 \\
\hline R3C4 & 4 & 6.79 & -2.79 & 7.784 & 1.146 \\
\hline R4C1 & 4 & 2.93 & 1.07 & 1.45 & 0.390 \\
\hline R4C2 & 0 & 0 & 0 & 0 & 0 \\
\hline R4C3 & 0 & 0 & 0 & 0 & 0 \\
\hline TOTAL & 98 & 98 & $\mathbf{0}$ & & 2.726 \\
\hline
\end{tabular}

Degree of freedom $=(\mathrm{R}-1) \times(\mathrm{c}-1)$ $=(3-1) \times(5-1)=8$

Level of significance $=5 \%$, i.e., 0.05

\section{Interpretation}

At 5\% level of significance and 8 degrees of freedom, the calculated value of Chi-Square is 2.726 , and the table value is 15.507. The calculated value is less than the table value. Hence the null hypothesis is accepted.

\section{RESULTS}

Majority 59\% of the respondents are between 21-30 ages.

- Majority $53 \%$ of the respondents are female.

- Most 59\% of the respondents have a place with scholarly capability.

- Most $69 \%$ of the respondents unmarried.

- Majority $45 \%$ of the respondents under 2 years experience.

- Majority $46 \%$ of the respondents known organization through occupation gateways.

- Majority $31 \%$ of the respondents enrolled from grounds enlistment.

- Majority $66 \%$ of the respondents says that organization notoriety was generally excellent[19],[21],[23]

- Majority $62 \%$ of the respondents says that the bent test was hard.

- Majority 57\% of the respondents says that the specialized test was typical.

- Majority $47 \%$ of the respondents says that the oral test was ordinary.

- Majority $47 \%$ of the respondents says that machine test was hard.

- Majority $100 \%$ of the respondents says that were the theme talked about during the meeting was pertinent to the activity.

- Majority $61 \%$ of the respondents says that the selection representative - recruitee relationship was excellent.

- Majority $100 \%$ of the respondents says that the determination procedure isn't one-sided in KGISL.

- Majority $41 \%$ of the respondents concur that the enlistment technique embraced by KGISL was dependable.

- Majority 54\% of the respondents concur that the 15-30 minutes time taken by KGISL at the season of enlistment.

- Majority $56 \%$ of the respondents unequivocally concur that the time taken for finishing the enlistment procedure in KGISL.

- Majority $54 \%$ of the respondents says that specialized capability does not impact the enlistment.

- Majority $69 \%$ of the respondents concur that the spotter information was high.

- Majority $100 \%$ of the respondents concur that the selecting group convey the precise activity Opinion at the season of enlistment.

- Majority $65 \%$ of the respondents concur that does the association take competitors input during post enrollment period[20],[22],[24].

- Majority $100 \%$ of the respondents concur that the organization post enrollment input session is finished by transparently.

- Majority $59 \%$ of the respondents concur their proposal executed in the following enrollment process.

- Majority $46 \%$ of the respondents profoundly happy with their activity.

- Majority $46 \%$ of the respondents very happy with the general enlistment process 


\section{V.CHI SQUARE FINDINGS}

- The test demonstrates that there is huge connection between the experience and employment fulfillment. In this way, the elective theory is acknowledged.

- The test demonstrates that there is no critical connection between the age and employment fulfillment. In this way, the invalid theory is acknowledged[25],[27],[29]

\section{DISCUSSIONS}

- The organization needs to favor the Consultancy administrations might be utilized for enlistment process in the territories like sourcing, short posting, and screening.

- The organization may stretch out the media of inclusion to local just as nearby level by giving notice in neighborhood every day and focus on news, magazines to neighborhood enrollment.

- The organization needs to expand the time span of the enrollment to underneath 30 minutes.

- The generally speaking enrollment test must be altered by the evolving patterns[26],[28],[30].

- In selecting IT/ITES experts the specialized capability ought to be considered.

\section{CONCLUSION}

Enlistment is a significant piece of a business human asset arranging. The general point of the enlistment procedure is to get the number and nature of workers that are required all together for the business to accomplish its destinations. Enlistment is ending up increasingly more significant in business. Specifically, this mirrors the expanding requirement for a well-roused and adaptable workforce that requires less administration supervision. Effective enrollment requires: proficient arranging, imaginative methodologies to get a quality field of candidates, testing of candidate's aptitudes and characteristics, boards with proper skill and judgment, quality basic leadership, pledge to assorted variety and reasonableness, and duty to quality, best practice forms that present an expert picture. Enrollment has consistently been critical to associations holding their focused edge. Having the correct procedures can enable you to choose the best potential competitors[31],[33]. Selecting another colleague ought to be supported by an unmistakable meaning of the necessities of the job. The prerequisites set out the information abilities and Behavior required and in that capacity gives a lot of criteria against which you can evaluate applicants and abstain from pulling in improper competitors.

\section{REFERENCES}

1) BharthVajan R., Ramachandran S.,Psychographic dimensions of training,2016,International Journal of Pharmacy and Technology,V-8,I-4,P-23727-23729

2) Balakrishnan P., Bharthvajan R.,A study on human resource planning in hospitals in Chennai City,2014,International Journal of Applied Engineering Research,V-9,I-22,P-7503-7507
3) Priyadarsini P., Bharthvajan R.,Role of emotional intelligence training programme in reducing the stress of the nurses,2014,International Journal of Applied Engineering Research,V-9,I-22,P-7411-7421

4) Kerinab Beenu G., Bharthvajan R.,Empirical analysis on the cosmetic buying behavior of young women in South India,2014,International Journal of Applied Engineering Research,V-9,I-22,P-7361-7366

5) Balakrishnan P., Bharthvajan R.,Whistling in the wind,2014,International Journal of Applied Engineering Research,V-9,I-22,P-7586-7593

6) Krishnan B., Peter M.,Health hazards of Indian Bpo employee-an alarming issue,2014,International Journal of Applied Engineering Research,V-9,I-22,P-7336-7341

7) Kerinab Beenu G.H., Peter M.,Role of insurance in economic development,2014,International Journal of Applied Engineering Research,V-9,I-22,P-7532-7539

8) Balakrishnan P., Peter M., Priyadarsini P.,Efficiency of safety measures for wellbeing of employees in manufacturing industry,2014,International Journal of Applied Engineering Research,V-9,I-22,P-7376-7382

9) Anbarasi M., Praveen Kumar S.,Online sales promotions of herbal products and its effectiveness towards tanisha.com,2019,Indian Journal of Public Health Research and Development,V-10,I-1,P-195-200

10) Anbarasi M., Praveen Kumar S.,Various online marketing and promotions strategies to improve the validation towards the organic products in the pharmaceutical sectors,2019,Indian Journal of Public Health Research and Development,V-10,I-1,P-263-269

11) Loganathan R., Praveen Kumar S.,Grievance handling a key factor for solving issues of employees in an organization,2014,International Journal of Applied Engineering Research,V-9,I-22,P-7483-7491

12) Loganathan R., Praveen Kumar S.,Study on preference of private label brands in super and Hypermarkets,2014,International Journal of Applied Engineering Research,V-9,I-22,P-7327-7335

13) Smitha M., Praveen Kumar S.,Understanding stress and its managementamong the nurses in Chennai city,2014,International Journal of Applied Engineering Research,V-9,I-22,P-7560-7565

14) Kerinab Beenu G.H., Praveen Kumar S.,A study on the investment behavior of Chennai investors in mutual fund schemes,2014,International Journal of Applied Engineering Research,V-9,I-22,P-7520-7525

15) Loganathan R., Praveen Kumar S.,Retention strategies key for organizational productivity,2014,International Journal of Applied Engineering Research,V-9,I-22,P-7443-7447

16) Pavithra J., Ganesan M., Brindha G.,State wise analysis of microfinance sector in India,2016,International Journal of Pharmacy and Technology,V-8,I-4,P-23417-23432

17) Pavithra J., Ganesan M.,A comparative study on microfinance in India and abroad,2016,International Journal of Applied Business and Economic Research,V-14,I-8,P-5471-5476

18) Pavithra J., Ganesan M.,A study on awareness and impact of micro-financial schemes,2016,International Journal of Applied Business and Economic Research,V-14,I-8,P-5449-5460

19) Senthilmurugan P., Pavithra J.,Consumer preference towards organised retailing with reference to Big Bazaar,2014,International Journal of Applied Engineering Research,V-9,I-22,P-7469-7475

20) Senthilmurugan P., Pavithra J.,Implication of social media marketing in growing healthcare industry,2014,International Journal of Applied Engineering Research,V-9,I-22,P-7448-7456

21) Loganathan R., Pavithra J.,Consumer perception towards private label brand over other brands in super markets and hypermarkets,2014,International Journal of Applied Engineering Research,V-9,I-22,P-7355-7360

22) Kerinab Beenu G., Pavithra J.,Tradeâ€"off between liquidity and profitability in logistics industry,2014,International Journal of Applied Engineering Research,V-9,I-22,P-7398-7401

23) Kerinab Beenu G., Pavithra J.,A study on the prospective consumerâ€(M perception towards utility cars in Chennai city,2014,International Journal of Applied Engineering Research,V-9,I-22,P-7526-7531

24) Pavithra J., Dilli Babu P., Ambuli T.V.,A study on budgetary control at Maruti Service Masters, Chennai,2014,International Journal of Applied Business and Economic Research,V-12,I-2,P-151-161

25) Pavithra J., Dilli Babu P., Ambuli T.V.,A study on customer satisfaction of retro Garments Pvt Ltd, Chennai,2014,International Journal of Applied Business and Economic Research,V-12,I-2,P-381-391

26) Kerinab Beenu G.H., Pavithra J., Senthilmurugan P.,A study on the influence of promotional activities for TATA ARIA among consumers in Chennai,2014,International Journal of Applied Engineering Research,V-9,I-22,P-7572-7578

27) Vijayaragavan S.P.,An investigative expert that's general FBG sensors,International Journal of Mechanical Engineering and Technology,V-8,I-8,PP-1500-1505,Y-2017

28) Vijayaragavan S.P.,Equalization routing protocol for Wi-Fi sensor strategy,International Journal of Mechanical Engineering and 
Technology,V-8,I-8,PP-1662-1666,Y-2017

29) Karthik B., Kiran Kumar T.V.U., Vijayaragavan P., Bharath Kumaran E.,Design of a digital PLL using $0.35 \hat{\mathrm{I}}^{1 / 4 \mathrm{~m}}$ CMOS technology,Middle East Journal of Scientific Research,V-18,I-12,PP-1803-1806,Y-2013

30) Kanniga E., Selvaramarathnam K., Sundararajan M.,Kandigital bike operating system,Middle - East Journal of Scientific Research,V

31) Jasmin M., Vigneshwaran T., Beulah Hemalatha S.,Design of power aware on chip embedded memory based FSM encoding in FPGA,International Journal of Applied Engineering Research,V-10,I-2,PP-4487-4496,Y-2015

32) Jasmin M.,Optimization techniques for low power VLSI circuits,Middle East Journal of Scientific Research,V-20,I-9,PP-1082-1087,Y-2014

33) Jasmin M., Vigneswaran T.,Fuzzy controller for error control of on - Chip communication,2017 International Conference on Algorithms, Methodology, Models and Applications in Emerging Technologies, ICAMMAET 2017,V-2017-January,I-,PP-1-5,Y-2017

\section{AUTHORS PROFILE}

Nandha Kumar Research Scholar, Department of MBA, Bharath Institute of Higher Education and Research, Chennai, India.

Dr S Praveen Kumar Professor, Department of MBA,

Bharath Institute of Higher Education and Research, Chennai, India. 